\title{
Percipirana raspodjela obiteljskih obveza među partnerima i doživljaj pravednosti u vezi
}

\author{
Andreja Bartolac \\ Zdravstveno veleučilište, Zagreb, Hrvatska \\ e-mail:andreja.bartolac@zvu.hr
}

Željka Kamenov

Filozofski fakultet Sveučilišta u Zagrebu, Odsjek za psihologiju, Hrvatska e-mail: zkamenov@ffzg.hr

SAŽETAK Istraživanja provedena tijekom posljednjih dvadesetak godina ukazuju na trend sve većeg deklarativnog slaganja žena i muškaraca o ravnopravnijoj raspodjeli obiteljskih obveza među partnerima. No u svakodnevnom životu ti se stavovi teško pretaču u djelovanje. Ovim istraživanjem cilj nam je bio saznati kako partneri percipiraju raspodjelu svakodnevnih obveza i odgovornosti u svojoj vezi u području obavljanja kućanskih poslova, upravljanja financijama i odlučivanju te kakvo je njihovo zadovoljstvo navedenom raspodjelom. Također nas je zanimala razlika između žena i muškaraca u percepciji pravednosti u vezi, odnosno predviđa li bolje doživljaj pravednosti u vezi percipirana raspodjela obiteljskih obveza ili zadovoljstvo tom raspodjelom. U istraživanju je sudjelovalo 120 parova u kojima su oba partnera zaposlena. Rezultati su pokazali da žene i dalje više doprinose u rutinskim ili tradicionalno ženskim poslovima, dok muškarci više obavljaju povremene ili muške poslove. Žene su pritom i manje zadovoljne takvom raspodjelom poslova u kućanstvu, kao i raspodjelom financija, nego što su to muškarci. Oba partnera najzadovoljnija su kada podjednako sudjeluju u obiteljskim troškovima i donošenju odluka. Doživljaj pravednosti u vezi najbolje se može predvidjeti zadovoljstvom raspodjelom financija kod muškaraca te zadovoljstvom raspodjelom kućanskih poslova u žena. Dodatno, zadovoljstvo raspodjelom odlučivanja značajan je prediktor za oba partnera.

Ključne riječi: raspodjela partnerskih obveza, zadovoljstvo, pravednost, dvohraniteljske obitelji. 


\section{Uvod}

"Svaki dom je kombinacija hotela, restorana, praonice, a često i dječjeg vrtića i igraonice. Svakodnevni radni napor koji treba uložiti u te aktivnosti obično je nevidljiv osobama koje od njih imaju koristi, naročito djeci i supruzima, koji se mogu izjednačiti s korisnicima koji sve dobiju besplatno. Situacija se polako mijenja, no žene još uvijek rade većinu kućanskih poslova, iako muškarci rade istu vrstu poslova izvan kuće, za plaću, radeći kao kuhari, konobari ili domari" (Coltrane i Shih, 2010.:403).

Obitelji dvostrukog hranitelja (Čudina-Obradović i Obradović, 2006.), odnosno zajednice u kojima su oba partnera zaposlena, danas su dominantne u hrvatskom društvu ${ }^{1}$. Ulaskom na tržište rada i razvijanjem karijere žene izlaze iz tradicionalnih rodnih uloga vezanih uz obitelj i domaćinstvo, osobito profiliranjem na radna mjesta na kojima je žena nositelj velike poslovne odgovornosti i na kojima napreduje u statusnom smislu. Unatoč tome trenutno u hrvatskim obiteljima žene još uvijek obavljaju većinu kućanskih poslova, neovisno o dobi, stupnju obrazovanja ili (ne) urbaniziranosti sredine u kojoj žive, ističu Kamenov i Jugović (2011.) u istraživanju $s$ nacionalno reprezentativnim uzorkom sudionika.

S obzirom na zahtjevnost poslovne uloge, postavlja se pitanje rade li žene koje su zaposlene izvan doma manje poslova veznih uz obitelj? Wilkie, Ferree i Ratcliff (1998.) zaključuju da ravnopravnija podjela hraniteljske uloge donosi više pogodnosti za muževe nego za žene, dok ravnopravnija podjela kućanskih odgovornosti nudi više prednosti za žene nego za muškarce. Bartley (2005.) je sa suradnicama istražila podjelu poslova u domaćinstvu u kojem su oba partnera zaposlena te njihovo zadovoljstvo vezom s obzirom na pojedinačni ulog. U većini takvih obitelji kućanski zadaci i dalje se dijele tako da podržavaju tradicionalne rodne uloge, odnosno žene su najčešće odgovorne za obavljanje dvije trećine poslova u domaćinstvu (Lennon i Rosenfield, 1994.; Coltrane, 2000.; Bartley i sur., 2005.). Prema posljednje navedenom američkom istraživanju, muževi su tijekom tjedna provodili prosječno 20 sati obavljajući poslove u domaćinstvu, a žene prosječno 34 sata tjedno. U longitudinalnom australskom istraživanju taj omjer čak je veći; žene koje su cijelo vrijeme bile u braku ili su se u međuvremenu rastale od svojih supruga tjedno su obavljale kućanske poslove tijekom 21-24 sata, a muškarci samo 9 sati (Baxter i sur., 2004.). Ipak razvedeni su muškarci znatno više vremena provodili obavljajući kućanske poslove nego što su to činili dok su bili u braku, što ponovno upućuje na rodno uvjetovanu podjelu poslova, ukoliko je ona moguća.

Bartley i suradnice (2005.) kategorizirale su poslove u kućanstvu kao poslove s niskom mogućnosti kontrole (tradicionalno „ženski poslovi“) i visokom mogućnosti kontrole (tradicionalno „muški poslovi“). Zadaci s niskom mogućnošću kontrole uključuju neodgodive rutinske poslove koji moraju biti obavljeni svakodnevno u točno određeno vrijeme, što ostavlja malo ili nimalo kontrole nad odabirom zada-

1 Prema podacima Državnog zavoda za statistiku, u 2011. godini od ukupnog broja zaposlenih gotovo $46 \%$ čine žene. 
taka i raspodjelom vremena. To su ujedno rutinski zadaci koji se obavljaju kako bi služili drugima, odnosno druge osobe (najčešće članovi obitelji) ovise o njima kako bi zadovoljile svoje osnovne potrebe. Također su dugotrajni, ponavljajući i slijede dnevni/tjedni raspored s malo vremenske fleksibilnosti (Topolčić, 2001.). Nasuprot tome zadaci s visokom mogućnošću kontrole, ili tradicionalno „muški poslovi“, obavljaju se povremeno, prema vlastitom nahođenju onoga tko ih obavlja, imaju definirano trajanje (početak i završetak) i nemaju specifično vrijeme u kojem se moraju obaviti, odnosno mogu se obaviti „kada budem imao vremena“. Ovakvi zadaci nemaju izravan utjecaj na zadovoljavanje osnovnih, dnevnih potreba drugog člana obitelji/kućanstva, a odgađanje njihovog dovršavanja neće imati utjecaj na druge niti će načelno poremetiti odnose u obitelji. Pokazalo se da žene provode triput više vremena obavljajući rutinske poslove nego njihovi muževi (Bartley i sur., 2005.).

Istraživanja su pokazala da je vrijeme provedeno u zadacima s niskom mogućnošću kontrole povećalo osjećaj nepravednosti i nejednakosti i u žena i muškaraca, dok je postizanje pravednosti u raspodijeli rutinskih zadataka u domaćinstvu imalo veći utjecaj na osjećaj zadovoljstva u žena (Bartley i sur., 2005.; Rogers i Amato, 2000.). S druge strane, sati provedeni u zadacima s visokom mogućnošću kontrole, koji se tradicionalno povezuju s muškim kućanskim poslovima, nisu imali utjecaja na percepciju pravednosti. Prema tome čini se da presudan čimbenik nije bio samo broj sati provedenih u aktivnostima u kući, već i vrsta zadataka koji su se trebali obaviti u to vrijeme (Ruppanner, 2008.). Također se pokazalo da je prevladavajuća uključenost u repetitivne kućanske poslove ili ispunjavanje potreba drugih povezana $\mathrm{s}$ tjelesnim znakovima umora, psihološkim stresom, osjećajem nepravednosti kao i lošijom kvalitetom bračnog života uz povećanje konflikta unutar braka (Coltrane, 2000; Bartley i sur., 2005.).

Percepcija pravednosti u preuzimanju i obavljanju kućanskih poslova ne znači da se poslovi dijele ujednačeno s obzirom da većina žena $(60,8 \%)$ i muškaraca $(67,5 \%)$ vjeruju da bi žene trebale raditi dvije trećine poslova u kući, odnosno da je prihvatljivo ako muškarac obavlja jednu trećinu kućanskih poslova (Lennon i Rosenfeld, 1994.). Naime u istom istraživanju muškarci smatraju da je pravedno ako doprinose poslovima u kući 36\% vremena, a žene ako one sudjeluju u 66\% od ukupnog vremena tijekom kojeg se obavljaju kućanski poslovi. Takav nalaz mogao bi donekle objasniti razloge zbog kojih žene znaju izražavati relativno zadovoljstvo pojedinačnim ulaganjem u svakodnevne poslove, iako oni očito nisu jednako raspodijeljeni. Unatoč tome vjerojatnije je da će zaposlene žene, za razliku od domaćica, očekivati od svojih supruga ravnopravniju podjelu kućanskih poslova (Potuchek, 1992.) iz čisto pragmatičnog razloga nedostatka vremena, ali i iz potrebe za poštivanjem njenog financijskog doprinosa obitelji. Sukladno tome vjerojatnije je da će žene koje su obrazovanije i više zarađuju doživljavati tradicionalnu podjelu kućanskih poslova kao nepravednu (Mederer, 1993.; Lennon i Rosenfield, 1994.).

Zašto žene prihvaćaju nejednaku podjelu opterećenja u domaćinstvu iako to od njih zahtijeva mnogo energije i vremena? Hochshield (1989., prema Lennon i Rosenfield, 1994.) nudi provokativnu pretpostavku da je ženina nada u veću ravnopravnost u raspodjeli kućanskih poslova oslabljena vlastitom nižom plaćom i poslovnim statu- 
som kao i opasnošću od razvoda, koji bi značajno smanjio njihov životni standard. Uočavanje sve većeg broja razvedenih brakova u vlastitoj okolini ${ }^{2}$ potiče ženu na razmišljanje kako mora preuzeti veći dio posla na sebe ne bi li njezin suprug bio zadovoljniji. Kako je razvod braka financijski i socijalno znatno više ugrožavajući za žene nego za muškarce, Hochshield smatra da i taj (pod)svjesni strah može sprječavati žene da traže više pomoći u „drugoj smjeni“. Obavljanje 60\% posla u kući čini se kao bolja alternativa od obavljanja 100\%. Sukladno tome Lennon i Rosenfield (1994.) smatraju da ženina percepcija pravednosti ovisi kako o njenim prihodima tako i o životnim opcijama izvan braka. Žene koje osjećaju da imaju manje životnih alternativa osim udaje i žene koje zarađuju toliko malo da bi bile na granici siromaštva ako bi se razvele vjerojatnije će nepravednu raspodjelu kućanskih poslova doživjeti prihvatljivom. Prema tome ženina financijska, odnosno egzistencijalna ovisnost o braku utječe na njezino doživljavanje pravednosti. Dodatno objašnjenje koje nude Lennon i Rosenfield (1994.) odnosi se na pronalaženje opravdanja za nejednakost u obavljanju poslova u kući, odnosno na rješavanje kognitivne disonance. U slučajevima u kojima žena ima nisku razinu moći nejednakost se može opravdati time da muškarac više radi na radnom mjestu, da nikada nije obavljao kućanske poslove prije braka ili da jednostavno nema sposobnosti za to, odnosno da će ona to ionako napraviti brže i kvalitetnije. Mederer (1993.) tvrdi da se žene čak opiru sudjelovanju svojih partnera u kućanskim poslovima iz razloga što im upravljanje domaćinstvom služi kao izvor moći te istovremeno potvrđuje njihov tradicionalan „ženski identitet“. Johnson (2010.) smatra da partneri koriste raspodjelu kućanskih obveza kako bi uzajamno oblikovali svoj rodni identitet, simbolički komunicirali sa svojim partnerom/icom te prikupili emocionalnu energiju. U prilog tome govore i nalazi da je povećanje ženine zarade povezano s njenim manjim udjelom u kućanskim poslovima samo do granice dok ne prelazi zaradu supruga (Bittman i sur., 2003.). U mnogim je istraživanjima pronađeno da parovi koji odstupaju od normativnih (npr. muž zarađuje manje od žene) imaju tradicionalniju podjelu kućanskih poslova (Bittman i sur., 2003; Brines, 1994; Greenstein, 2000; Pyke, 1994; Tichenor, 2005). Drugim riječima, što je suprug ovisniji o zaradi žene, to se manje uključuje u obavljanje rutinskih kućanskih poslova. Na taj način, uz pomoć raspodjele poslova u obitelji, i muškarac i žena pokušavaju zadržati svoj rodni identitet unatoč zamjeni rodnih uloga u pogledu privređivanja za obitelj (Brines, 1994.). Sukladno tome Major (1993.) zaključuje da rod, više od bilo kojeg drugog čimbenika, doprinosi načinu na koji su raspodijeljene odgovornosti u obitelji.

Nasuprot dugogodišnjem svjetskom trendu istraživanja podjele rada u kućanstvu između bračnih partnera, u Hrvatskoj od početka 70-ih godina pa do sredine 90ih godina nema empirijskih istraživanja tog problema. Prema Topolčiću (2001.), nedostatak znanstvenog interesa za ovaj problem ima svoje korijene u društvenim okolnostima: u socijalističkom razdoblju u sferi javnih odnosa proklamirana je

2 Tijekom 2007. godine na 1000 sklopljenih brakova u Hrvatskoj je bilo 207 razvedenih (prema DZS, 2009.), dok je u Sjedinjenim Američkim državama bilo 394 razvedenih na 1000 sklopljenih brakova (prema podacima Nacionalnog centra za zdravstvenu statistiku (National Center for Health Statistics)). 
jednakost spolova bez zadiranja u sferu privatnosti i obiteljskih odnosa. Dostupna hrvatska istraživanja percepcije ravnopravnosti podjele obiteljskih uloga, provedena unatrag desetak godina, pokazuju da se muškarci i žene slažu u percepciji da žene u Hrvatskoj preuzimaju na sebe većinu kućanskih poslova, brige o djeci i starijim i nemoćnim članovima obitelji (Leinert Novosel, 1999.; Tomić-Koludrović i Kunac, 2000.; Kamenov i sur., 2007.). Percipira se da žene imaju malo slobodnog vremena te da ga uglavnom provode u obavljanju kućanskih poslova i bavljenju djecom, što govori o dvostrukoj opterećenosti žena, te da muškarci svoje slobodno vrijeme većinom provode u sportu i rekreaciji, političkoj djelatnosti i u zabavi (Leinert Novosel, 1999.). Ispitivanje 3200 žena iz četiriju hrvatskih županija o podjeli kućanskih poslova (Tomić-Koludrović i Kunac, 2000.) pokazalo je da žene smatraju da muškarci obavljaju većinu lakših popravaka kućanskih aparata i točenja goriva u automobile, dok žene većinom obavljaju poslove kao što su pospremanje stola nakon objeda, čišćenje podova, pranje posuđa, kuhanje, glačanje i pranje rublja.

Posljednje veliko istraživanje ove teme (Kamenov i Jugović, 2011.) pokazalo je da, prema procjenama sudionika/ca, u većini obitelji oboje partnera prilično ravnopravno sudjeluje u donošenju važnih odluka i upravljanju obiteljskim novcem. Nešto manje ravnopravnu podjelu u ovom aspektu obiteljskog života primjećuju građani/ke stariji od 60 godina, niže obrazovani i sudionici/e iz seoskih sredina. Malo drugačija slika dobiva se u pogledu raspodjele brige oko djece i pridavanja važnosti poslu/ karijeri partnera. Oko tri četvrtine sudionika/ca percipira rodnu neravnopravnost u ovim aspektima, i to na štetu žena. Veću neravnopravnost percipiraju osobe starije od 45 godina te niže obrazovane. Konačno, najmanje rodne ravnopravnosti ostvareno je u pogledu raspodjele kućanskih poslova. U ovom aspektu podjele obiteljskih uloga ni jedna sociodemografska varijabla nije se pokazala značajnom.

Na koji se način ispituje raspodjela poslova u dosadašnjim istraživanjima u području? Coltrane i Shih (2010.) navode da su ranije studije ispitivale ukupno vrijeme svih muškaraca i žena provedeno u kućanskim poslovima, dok su novija istraživanja dijadna - orijentiraju se na dinamiku u parovima, koriste proporcionalne mjere i prikupljaju podatke od obaju partnera u istom kućanstvu, uzimajući u obzir i rodnu tipiziranost određenih poslova. Najčešće se koriste vremenski dnevnici (engl. time diaries) i anketni upitnici primijenjeni putem telefona, pošte ili licem u lice. Oba se partnera pita direktno o utrošenom vremenu (tijekom zadnja 24 sata) ili o raspodjeli poslova (npr. «Tko je zadužen za pojedini posao? - uvijek ja, uglavnom ja, oboje podjednako, uglavnom partner, uvijek partner») (Gunter i Gunter, 1990.; Lindsay, 1999.; Ruppaner, 2008.; Goñi-Legaz i sur., 2010.). Rjeđe se koriste dubinski intervjui ili direktno opažanje. Usporedba podataka iz vremenskih dnevnika i anketnih istraživanja o utrošenom vremenu za pojedine kućanske poslove pokazala je da sudionici u anketama obično precjenjuju vrijeme potrošeno u rutinskim poslovima, a podcjenjuju ono u povremenim poslovima (Coltrane, 2000.). Međutim kada ih se pita o procjeni raspodjele pojedinih poslova unutar para, odgovori su gotovo istovjetni podacima prikupljenim vremenskim dnevnicima (Sullivan, 1997., Man Yee, 2008.). 


\section{Cilj, problemi i hipoteze}

Cilj ovog istraživanja bio je ispitati percepciju pravednosti s obzirom na percipiranu raspodjelu obiteljskih obveza među partnerima i zadovoljstvo ostvarenom raspodjelom. Iako bi mjerenje stvarne raspodjele pružilo objektivnije podatke, teorija socijalne razmjene (Kelley i Thibaut, 1978.) i teorija jednakosti (Homans, 1961.; Walster, Walster i Berscheid, 1978.), kao i brojni empirijski nalazi, upućuju da je percepcija pravednosti i zadovoljstvo vezom određena percepcijom pojedinca o raspodjeli ulaganja među partnerima, a ne objektivnim stanjem. Također, kako se početna očekivanja o raspodjeli obiteljskih obveza razlikuju od osobe do osobe, ovisno o njihovom rodnom identitetu i tradicionalnosti stavova o rodnim ulogama (Frieze i sur., 2003.; Jugović, 2004.; Bartolac i sur., 2011.), istom raspodjelom obveza različite osobe mogu biti različito zadovoljne, te je stoga u ispitivanju percepcije pravednosti u vezi važno zahvatiti i ovo zadovoljstvo raspodjelom neovisno o samoj raspodjeli.

U skladu s postavljenim ciljem istraživanja, formulirana su četiri istraživačka problema. Unutar prvog problema cilj nam je ispitati percepciju partnera (žena i muškaraca) u ispitanom uzorku (izvan)bračnih parova o njihovom sudjelovanju u obiteljskim obvezama. Pritom nas zanima njihov doživljaj vlastitog i partnerovog te zajedničkog doprinosa u obavljanju kućanskih poslova, brizi oko djece, upravljanju financijama i donošenju odluka, odnosno koliko se oni međusobno slažu u svojim procjenama. Pretpostavljamo da će rezultati ukazivati na tradicionalnu podjelu obiteljskih obveza, odnosno da će žene više obavljati repetitivne kućanske poslove s niskom mogućnošću kontrole, dok će muškarci više doprinositi obavljanju povremenih kućanskih poslova s visokom mogućnošću kontrole (Bartley, Blanton i Gilliard, 2005.). Također, donošenje odluka i upravljanje financijama bit ce tradicionalno više zastupljene u muškaraca.

Drugi problem odnosi se na utvrđivanje zadovoljstva sudionika percipiranom raspodjelom navedenih obveza. Očekujemo da će općenito žene biti manje zadovoljne nego muškarci, kao i da će najzadovoljniji biti sudionici koji percipiraju kako su u njihovoj vezi obveze podjednako raspoređene među partnerima.

Trećim problemom ispituje se postoji li razlika u percepciji pravednosti u vezi među partnerima u svakom paru. Istraživanja potvrđuju da muškarci odnose u vezi doživljavaju pravednijima od žena (Ćubela-Adorić i Mičić, 2010.), te očekujemo jednak rezultat u zavisnom uzorku sudionika ovog istraživanja.

Četvrtim problemom istraženo je u kojoj se mjeri doživljaj pravednosti u vezi može predvidjeti percipiranom raspodjelom obiteljskih obveza, a u kojoj mjeri zadovoljstvom tom raspodjelom. Kako polazimo od pretpostavke da ce osobe biti zadovoljnije podjelom poslova koja odgovara njihovim očekivanjima neovisno o tome kako je raspodijeljeno opterećenje među partnerima, očekujemo da će zadovoljstvo raspodjelom biti bolji prediktor doživljaja pravednosti u vezi nego sama percipirana raspodjela. 


\section{Metodologija}

U istraživanju je sudjelovalo 120 parova koji žive u bračnoj ili izvanbračnoj zajednici barem godinu dana. U svim parovima oba partnera su zaposlena, najčešce u okviru ugovora na neodređeno vrijeme (njih 80,8\%). Sudionici čine prigodan uzorak roditelja i/ili odraslih poznanika studenata i nastavnika jednog zagrebačkog veleučilišta a s područja su središnje Hrvatske. Sudionici su prosječne dobi od 37 godina (žene), odnosno 39,5 godina (muškarci), pri čemu se raspon dobi kreće od 21 do 61 godine. Najveći broj sudionika odrastao je u velikom gradu (46,3\%) ili na selu (27,5\%). Od ukupnog broja sudionika njih 40,3\% imaju visoku, 20,2\% višu i 37,8\% srednju školsku spremu. Samo 18,3\% parova živi u izvanbračnoj zajednici, a $80 \%$ u formalnom braku. Parovi prosječno žive zajedno 12,57 godina $(\mathrm{sd}=8,92)$. Najveći broj roditelja ima jedno (29,7\%) ili dvoje $(37,7 \%)$ djece, dok 18,4\% parova nema djece.

Kako bi se procijenilo relativno ulaganje partnera u vezu, odnosno percipirana podjela odgovornosti, sudionici su ispunili tablične liste za označavanje triju područja funkcioniranja u vezi: raspodjelu financijskih izdataka, raspodjelu kućanskih poslova te odgovornost za donošenje odluka vezanih uz partnerstvo i/ili obitelj. Tablice, kao i način bodovanja, preuzete su iz istraživanja provedenog 2005. godine u okviru Ljetne škole Odsjeka za psihologiju Filozofskog fakulteta u Zagrebu tijekom koje su provjerene i potvrđene odgovarajuće psihometrijske karakteristike instrumenta (Tadinac i sur., 2007.). Zadatak je sudionika da u pojedinoj tablici označi vlastiti doživljaj raspodjele odgovornosti za navedeno područje u njihovoj vezi. Prilikom obrade podataka bodovanje odgovora sudionika za pojedino područje vrši se na sljedeći način:

Za procjenu podjele financijskih izdataka svaki odgovor u kategoriji „ja plaćam“ boduje se s 3 boda, u kategorijama „dijelimo izdatke prema mogućnosti plaćanja“ i „dijelimo izdatke po pola“ s 2 boda, a u kategoriji „partner/ica plaća“ s jednim bodom. Konačna mjera financijskog ulaganja formira se kao zbroj svih bodova podijeljen s ukupnim brojem odgovora (kategorija "ne odnosi se na nas“ ne ulazi u obradu).

- Za procjenu odgovornosti za izvršavanje kućanskih poslova i brige o djeci odgovori u kategorijama „uvijek ja“ i „obično ja“ boduju se s 3 boda, „partnerica i ja jednako“ s 2 boda, a „obično partner/ica“ i „uvijek partner/ica“ s jednim bodom.

- Kako bi se procijenilo tko u vezi donosi odluke vezane uz funkcioniranje zajednice/obitelji, bodovanje odgovora provodi se na jednak način kao i prethodno opisano.

Nakon svake procjene pojedinog područja funkcioniranja u vezi sudionici dodatno procjenjuju svoje zadovoljstvo navedenom raspodjelom financijskih izdataka, kućanskih poslova, odnosno donošenja odluka na skalama od 1 do 7 , pri čemu ocjena 1 odražava „potpuno nezadovoljstvo“, a ocjena 7 „potpuno zadovoljstvo"raspodjelom navedene odgovornosti.

Doživljaj pravednosti u vezi ispitan je Skalom percipirane pravednosti u braku (Ćubela Adorić, 2006.) koja je dio Upitnika percepcije kvalitete bračnog odnosa (UPKBO, Ćubela Adorić i Jurević, 2006.). Skala sadrži 11 tvrdnji vezanih uz percepciju 
pravednosti u vezi (primjerice: „Kad usporedim ono što ulažem u svoju vezu i što od nje dobivam s onim što u nju ulaže i dobiva moj partner/ica, mislim da nitko od nas nije na gubitku“) koje sudionik ocjenjuje na skali od 7 stupnjeva; od -3 do +3 . Pritom ocjena -3 označava da je tvrdnja „potpuno netočna“, a +3 tvrdnja je „potpuno točna“. Pri bodovanju se procjene kodiraju od 1 do 7 . Ukupan rezultat na skali određuje se kao prosječna vrijednost procjena na svim česticama, pa se teorijski raspon rezultata kreće između 1 i 7 . Pritom veći rezultat ukazuje na veću percipiranu pravednost odnosa s partnerom (Ćubela Adorić i Mičić, 2010.).

Posljednji dio upitnika namijenjen je prikupljanju sociodemografskih podataka o sudionicima a obuhvaća sljedeće varijable: spol, dob, stupanj obrazovanja, radni status, veličina mjesta prebivanja do 18. godine, bračni status, duljina zajedničkog života, broj i dob djece. Svaki upitnik konstruiran je u dvije paralelne forme: verzija za žene i verzija za muškarce.

Prikupljanje podataka provedeno je tijekom 2009. godine. Svaki anketar koji je dobrovoljno pristao na sudjelovanje u prikupljanju podataka upoznat je s uputom za sudionike. Anketari su uručili upitnik svakom partneru u paru ponaosob. Upitnici za svakog člana para prethodno su označeni šifrom te su se nalazili u zasebnim omotnicama. Tijekom ispitivanja članovi su para dobili uputu da samostalno odgovaraju na pitanja, bez međusobne komunikacije. Anketari su bili na raspolaganju sudionicima za eventualne nejasnoće tijekom ispunjavanja upitnika. Sudionici su sami vraćali ispunjeni upitnik u svoju omotnicu koju su zapečatili a anketar ju je dostavio istraživačima.

\section{Rezultati}

Prije negoli je provedena analiza rezultata u okviru prvog problema, provjereno je može li se ovaj uzorak sudionika smatrati cjelovitim po pitanju oblika partnerske zajednice (formalna i neformalna partnerska zajednica) te po pitanju broja i dobi djece u obitelji. Učinjena je serija $\chi^{2}$ testova s rezultatima percipirane raspodjele svih uključenih obiteljskih obveza. Rezultati su pokazali da se prema navedenom kriteriju parovi koji se nalaze u bračnoj zajednici ne razlikuju značajno od parova koji žive u izvanbračnoj zajednici (slično argumentira i Lindsay, 1999.). Dodatno je provjereno razlikuju li se u percipiranoj raspodjeli obiteljskih obveza parovi koji nemaju djece od onih koji imaju malu (predškolsku) djecu, osnovnoškolsku djecu te srednjoškolsku i stariju djecu (15+). Ove četiri skupine bile su podjednako zastupljene u cijelom uzorku te se ponovnom upotrebom $\chi^{2}$ testa nisu dobile razlike među skupinama ni za jednu česticu (pritom se posebno pazilo da u analizu obiteljskih obveza koje uključuju brigu o djeci (npr. dječje izvanškolske aktivnosti, briga o djeci, odluke o djeci) ne budu uključeni parovi koji nemaju djecu. I ponovno nisu pronađene razlike u odgovorima između ovih skupina. Stoga su u daljnjoj analizi svi parovi tretirani kao jedinstven uzorak.

Kao odgovor na prvi problem, podaci o osobnoj percepciji podjele obiteljskih obveza među partnerima prikazani su deskriptivno u obliku postotaka samoprocjene 
osobnog i/ili partnerovog sudjelovanja u navedenim poslovima s niskom i visokom mogućnošću kontrole, kao i brizi za druge, raspodjeli financija te donošenju odluka.

\section{Tablica 1.}

Deskriptivna statistika za skale percipirane raspodjele kućanskih poslova i brige za druge za žene i muškarce

\begin{tabular}{|c|c|c|c|c|c|c|c|}
\hline \multirow{2}{*}{ Vrsta posla } & \multirow{2}{*}{ Čestice } & \multicolumn{3}{|c|}{ ŽENE (\%) } & \multicolumn{3}{|c|}{ MUŠKARCI (\%) } \\
\hline & & $\mathrm{Ja}$ & Partner & Jednako & $\mathrm{Ja}$ & Partnerica & Jednako \\
\hline \multirow{6}{*}{$\begin{array}{l}\text { Rutinski } \\
\text { poslovi }\end{array}$} & Kuhanje & 75,0 & 5,8 & 16,7 & 9,2 & 76,5 & 12,6 \\
\hline & $\begin{array}{l}\text { Pranje i } \\
\text { glačanje rublja }\end{array}$ & 87,5 & 1,7 & 9,2 & 2,5 & 89,0 & 6,8 \\
\hline & $\begin{array}{l}\text { Pranje suđa i } \\
\text { pospremanje } \\
\text { stola }\end{array}$ & 51,7 & 3,3 & 43,3 & 9,3 & 53,4 & 36,4 \\
\hline & $\begin{array}{l}\text { Usisavanje i } \\
\text { brisanje prašine }\end{array}$ & 53,3 & 6,7 & 35,8 & 9,2 & 52,9 & 33,6 \\
\hline & $\begin{array}{l}\text { Pranje prozora, } \\
\text { podova i sl. }\end{array}$ & 73,3 & 3,3 & 18,3 & 5,0 & 66,4 & 23,5 \\
\hline & $\begin{array}{l}\text { Čišćenje } \\
\text { sanitarnih } \\
\text { prostorija }\end{array}$ & 73,3 & 7,5 & 16,7 & 8,4 & 65,5 & 22,7 \\
\hline \multirow{3}{*}{$\begin{array}{l}\text { Povremeni } \\
\text { poslovi }\end{array}$} & $\begin{array}{l}\text { Kućanski } \\
\text { popravci }\end{array}$ & 5,0 & 82,5 & 11,7 & 88,2 & 1,7 & 9,2 \\
\hline & $\begin{array}{l}\text { Briga o } \\
\text { okućnici* }\end{array}$ & 10,0 & 32,5 & 27,5 & 39,5 & 4,4 & 31,6 \\
\hline & $\begin{array}{l}\text { Popravci } \\
\text { automobila }\end{array}$ & 2,5 & 80,8 & 9,2 & 89,1 & 2,5 & 3,4 \\
\hline \multirow{2}{*}{$\begin{array}{l}\text { Briga za } \\
\text { druge }\end{array}$} & Briga za djecu & 19,2 & 0,8 & 66,7 & 1,8 & 20,4 & 69,0 \\
\hline & $\begin{array}{l}\text { Briga za kućne } \\
\text { ljubimce** }\end{array}$ & 8,3 & 14,2 & 28,3 & 20,9 & 14,5 & 23,6 \\
\hline \multirow{9}{*}{$\begin{array}{l}\text { Raspodjela } \\
\text { financija }\end{array}$} & $\begin{array}{l}\text { Troškovi } \\
\text { stanarine }\end{array}$ & 8,3 & 13,3 & 54,6 & 16,8 & 5,0 & 59,7 \\
\hline & Osiguranje & 4,2 & 17,5 & 68,3 & 24,6 & 4,2 & 61,9 \\
\hline & Računi & 9,2 & 18,3 & 67,5 & 22,7 & 6,7 & 63,9 \\
\hline & Namirnice & 15,8 & 5,0 & 74,2 & 2,5 & 11,9 & 80,5 \\
\hline & $\begin{array}{l}\text { Kućanski } \\
\text { popravci }\end{array}$ & 0,8 & 21,7 & 69,2 & 28,0 & 1,7 & 64,4 \\
\hline & $\begin{array}{l}\text { Troškovi za } \\
\text { automobil }\end{array}$ & 3,3 & 25 & 64,2 & 33,6 & 2,5 & 56,3 \\
\hline & Odjeća i obuća & 14,2 & 1,7 & 78,3 & 1,7 & 12,6 & 80,7 \\
\hline & $\begin{array}{l}\text { Dječje } \\
\text { izvanškolske } \\
\text { aktivnosti }\end{array}$ & 8,3 & 4,2 & 66,7 & 4,4 & 8,0 & 71,7 \\
\hline & $\begin{array}{l}\text { Ljetovanje/ } \\
\text { zimovanje }\end{array}$ & 2,5 & 11,7 & 76,7 & 10,9 & 3,4 & 77,3 \\
\hline
\end{tabular}




\begin{tabular}{|c|c|c|c|c|c|c|c|}
\hline \multirow{2}{*}{ Vrsta posla } & \multirow{2}{*}{ Čestice } & \multicolumn{3}{|c|}{ ŽENE (\%) } & \multicolumn{3}{|c|}{ MUŠKARCI (\%) } \\
\hline & & $\mathrm{Ja}$ & Partner & Jednako & $\mathrm{Ja}$ & Partnerica & Jednako \\
\hline \multirow{8}{*}{$\begin{array}{l}\text { Raspodjela } \\
\text { odlučivanja }\end{array}$} & $\begin{array}{l}\text { Koji automobil } \\
\text { kupiti }\end{array}$ & 0,8 & 35 & 61,7 & 42,0 & 4,2 & 53,8 \\
\hline & $\begin{array}{l}\text { Kupiti ili ne } \\
\text { kupiti životno } \\
\text { osiguranje }\end{array}$ & 5,8 & 11,7 & 76,7 & 13,4 & 9,2 & 70,6 \\
\hline & $\begin{array}{l}\text { Koliko novaca } \\
\text { zajedno trošiti } \\
\text { na hranu }\end{array}$ & 24,2 & 4,2 & 69,2 & 5,9 & 22,7 & 69,7 \\
\hline & $\begin{array}{l}\text { Kamo ići na } \\
\text { odmor }\end{array}$ & 10,0 & 5,8 & 82,5 & 5,9 & 11,8 & 79,8 \\
\hline & $\begin{array}{l}\text { Kako provoditi } \\
\text { slobodno } \\
\text { vrijeme }\end{array}$ & 12,5 & 3,3 & 83,3 & 6,7 & 14,3 & 78,2 \\
\hline & $\begin{array}{l}\text { S kojim } \\
\text { prijateljima } \\
\text { provoditi } \\
\text { vrijeme }\end{array}$ & 9,2 & 4,2 & 85,8 & 5,9 & 10,9 & 80,7 \\
\hline & Odluke o djeci & 20,8 & 0,0 & 65,8 & 1,8 & 23,0 & 66,4 \\
\hline & $\begin{array}{l}\text { Koju kuću ili } \\
\text { stan izabrati }\end{array}$ & 5 & 7,5 & 81,7 & 10,9 & 7,6 & 76,5 \\
\hline
\end{tabular}

*25,8\%: ne odnosi se na nas $\quad * * 40,8 \%$ : ne odnosi se na nas

Iz prikaza u tablici 1 . može se vidjeti kako se oba partnera slažu u procjeni da žene više doprinose u rutinskim ili tradicionalno „ženskim poslovima“ s niskom mogućnosti kontrole, dok muškarci više obavljaju povremene („muške“) poslove s visokom mogućnosti kontrole, osim brige o okućnici. Po pitanju raspodjele plaćanja financijskih izdataka vidljivo je kako većina partnera smatra da izdatke većinom dijele podjednako, no i kako se muškarci više brinu za plaćanje troškova za automobil, kućanskih popravaka, stanarine, računa ili osiguranja, dok se žene više brinu za plaćanje namirnica ili obuće i odjeće. Odluke se također donose pretežno zajednički, no muškarci češće odlučuju o tome koji automobil kupiti, a žene o kupovini namirnica i o djeci.

Kako bi se utvrdilo slaganje među partnerima vezano uz percepciju vlastitih i partnerovih ulaganja, provedena je serija $\chi^{2}$ testova za frekvencije raspodjele poslova, financija i odlučivanja ${ }^{3}$. Rezultati pokazuju da su, iako partneri neznatno precjenjuju vlastiti doprinos, muškarci i žene suglasni u procjeni vlastitog i partnerovog angažmana u obavljanju navedenih aktivnosti, odnosno nije dobivena ni jedna statistički značajna razlika u procjenama vlastitog i partnerovog ulaganja između žena i muškaraca u ovom uzorku sudionika. Stoga možemo zaključiti da je suglasnost partnera u percepciji njihovog sudjelovanja u obiteljskim zadacima bliska stvarnom ulaganju.

3 Detaljna tablica sa svim provedenim $\chi^{2}$-testovima može se dobiti od autora. 
Drugim smo problemom ispitale postoji li razlika u zadovoljstvu među partnerima s obzirom na percipirani doprinos pri raspodjeli obiteljskih obveza koristeći t-test za zavisne uzorke.

Tablica 2.

Deskriptivna statistika zadovoljstva raspodjelom investicija za parove s pripadajućim t-omjerima za zavisne uzorke

\begin{tabular}{|l|c|c|c|c|c|c|}
\hline Skala & $\mathbf{M}_{\boldsymbol{z}}$ & $\mathbf{S D}_{\mathbf{z}}$ & $\mathbf{M}_{\mathbf{m}}$ & $\mathbf{S D}_{\mathbf{m}}$ & $\mathbf{t}$ & $\mathbf{d f}$ \\
\hline $\begin{array}{l}\text { Zadovoljstvo raspodjelom } \\
\text { kućanskih poslova }\end{array}$ & 5,51 & 1,51 & 6,40 & 1,05 & $5,879^{* * * *}$ & 106 \\
\hline $\begin{array}{l}\text { Zadovoljstvo raspodjelom } \\
\text { financija }\end{array}$ & 6,17 & 1,26 & 6,51 & 0,87 & $2,963^{* *}$ & 110 \\
\hline $\begin{array}{l}\text { Zadovoljstvo donošenjem } \\
\text { odluka }\end{array}$ & 6,25 & 1,14 & 6,35 & 1,08 & 0,756 & 117 \\
\hline
\end{tabular}

$* * \mathrm{p}<.0,01 ; * * * \mathrm{p}<0,001$

Iz tablice 2. vidljivo je da je zadovoljstvo percipiranom raspodjelom obavljanja kućanskih poslova te raspodjelom financija kod žena značajno manje nego u muškaraca. Jedino su po pitanju percepcije sudjelovanja u donošenju odluka u vezi i muškarci i žene jednako zadovoljni.

Zanimalo nas je kakvom percipiranom raspodjelom obveza su žene, odnosno muškarci najviše, a kakvom najmanje zadovoljni. Da bismo to provjerili, podijelili smo parove u tri skupine: one u kojima pojedinu skupinu obveza uglavnom preuzima muškarac, one u kojima tu obvezu dijele podjednako te one u kojima obvezu uglavnom preuzima žena. Analizom varijance provjereno je razlikuju li se muškarci, odnosno žene iz ovih triju skupina parova u zadovoljstvu podjelom obveza. Rezultati su prikazani u tablici 3 .

Tablica 3.

Prikaz rezultata analize varijance: Razlika između muškaraca i žena u zadovoljstvu podjelom obiteljskih obveza s obzirom na pripadanje skupini parova u kojima većinu obveza preuzima žena, odnosno muškarac ili obveze preuzimaju podjednako

\begin{tabular}{|c|c|c|c|c|c|c|c|c|c|}
\hline Skala & Skupina & $M_{i}$ & $S D_{i}$ & $\mathbf{F}$ & df & $M_{m}$ & $S D_{m}$ & $\mathbf{F}$ & df \\
\hline \multirow{3}{*}{$\begin{array}{l}\text { Zadovoljstvo } \\
\text { raspodjelom } \\
\text { kućanskih } \\
\text { poslova }\end{array}$} & Ž radi više & 4,57 & 1,63 & \multirow{3}{*}{$16,56^{\text {***** }}$} & \multirow{3}{*}{$2 / 107$} & 6,40 & 0,55 & \multirow{3}{*}{0,250} & \multirow{3}{*}{$2 / 106$} \\
\hline & Podjednako & 5,91 & 1,15 & & & 6,28 & 0,96 & & \\
\hline & M radi više & 6,57 & 0,51 & & & 6,44 & 1,12 & & \\
\hline \multirow{3}{*}{$\begin{array}{l}\text { Zadovoljstvo } \\
\text { raspodjelom } \\
\text { financija }\end{array}$} & Ž radi više & 5,13 & 1,55 & \multirow{3}{*}{$11,29^{\text {***** }}$} & \multirow{3}{*}{$2 / 110$} & 6,50 & 0,84 & \multirow{3}{*}{$3,83^{*}$} & \multirow{3}{*}{$2 / 106$} \\
\hline & Podjednako & 6,58 & 0,81 & & & 6,68 & 0,79 & & \\
\hline & M radi više & 5,82 & 1,51 & & & 6,20 & 0,98 & & \\
\hline \multirow{3}{*}{$\begin{array}{l}\text { Zadovoljstvo } \\
\text { donošenjem } \\
\text { odluka }\end{array}$} & Ž radi više & 5,86 & 1,17 & \multirow{3}{*}{$8,66^{* * * * *}$} & \multirow{3}{*}{$2 / 100$} & 5,71 & 1,38 & \multirow{3}{*}{$12,23^{\text {**** }}$} & \multirow{3}{*}{$2 / 105$} \\
\hline & Podjednako & 6,69 & 0,68 & & & 6,80 & 0,53 & & \\
\hline & M radi više & 5,84 & 1,32 & & & 6,17 & 1,19 & & \\
\hline
\end{tabular}

${ }^{*} p<.05,{ }^{* * *} p<.001$ Značajne razlike među skupinama prema Post-hoc Scheffé testovima označene su podebljanim slovima $M$ vrijednosti 
Razlika među spolovima u zadovoljstvu podjelom kućanskih poslova prikazana u tablici 2. može se objasniti dobivenim rezultatima analize varijance prema kojima su muškarci u svim trima skupinama parova podjednako zadovoljni percipiranom raspodjelom poslova, dok su žene to zadovoljnije što partner više sudjeluje u kućanskim poslovima. U pogledu podjele financija, i muškarci i žene najzadovoljniji su ako podjednako sudjeluju u plaćanju obiteljskih troškova, a najmanje zadovoljni ako sami snose većinu troškova. Naposljetku, muškarci i žene ne razlikuju se u pogledu zadovoljstva raspodjelom u donošenju odluka - i jedni i drugi najzadovoljniji su ako odluke donose zajednički.

Treći problem odnosio se na pitanje doživljavaju li partneri različito pravednost u vezi? Rezultat provedenog t-testa za zavisne uzorke ukazuje na značajnu razliku između partnera u percepciji pravednosti u vezi $(\mathrm{t}=7,213, \mathrm{df}=110, \mathrm{p}<0,001)$, a pritom žene $(M=4,85 ; \mathrm{SD}=0,94)$ doživljavaju odnos u vezi manje pravednim od muškaraca $(\mathrm{M}=5,66 ; \mathrm{SD}=1,07)$. Analizom odgovora na pojedinim česticama Skale percipirane pravednosti u braku uočavamo da muškarcima odgovara način na koji dijele svakodnevne obveze i odgovornosti s partnericom, smatraju da su voljni pomoći jedno drugome oko svakodnevnih poslova kao i da podjednako nose teret obveza i odgovornosti u njihovoj vezi. Nasuprot tome ženama je značajno manje prihvatljiv način raspodjele svakodnevnih obveza, manje primjećuju volju svog partnera za sudjelovanjem u svakodnevnim poslovima i osjećaju da nose prevelik dio odgovornosti za njihov zajednički život.

$\mathrm{Na}$ četvrti problem odgovoreno je hijerarhijskom regresijskom analizom u dva koraka kojom smo ispitale koliko percepciji pravednosti u vezi doprinosi percipirana raspodjela poslova/financija/odlučivanja, a koliko zadovoljstvo navedenom raspodjelom.

\section{Tablica 4.}

Prikaz rezultata hijerarhijske regresijske analize: Doprinos percipirane raspodjele poslova/financija/ odlučivanja i zadovoljstva navedenom raspodjelom doživljaju pravednosti za žene i muškarce

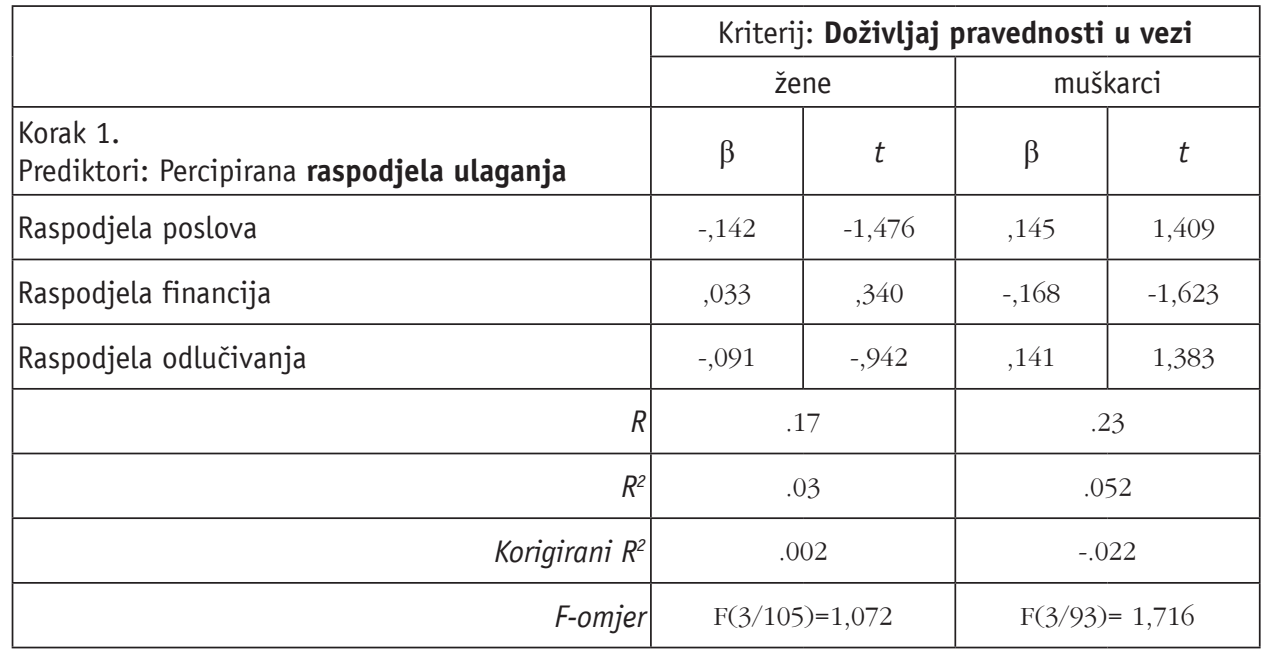




\begin{tabular}{|c|c|c|c|c|}
\hline \multirow[b]{3}{*}{$\begin{array}{l}\text { Korak } 2 . \\
\text { Prediktori: Zadovoljstvo raspodjelom ulaganja }\end{array}$} & \multicolumn{4}{|c|}{ Kriterij: Doživljaj pravednosti u vezi } \\
\hline & \multicolumn{2}{|c|}{ žene } & \multicolumn{2}{|c|}{ muškarci } \\
\hline & $\beta$ & $\mathrm{t}$ & $\beta$ & $\mathrm{t}$ \\
\hline Raspodjela poslova & 024 & 243 &, 140 & 1,722 \\
\hline Raspodjela financija & 086 & ,968 &,- 050 &,- 604 \\
\hline Raspodjela odlučivanja &,- 130 & $-1,485$ &, 021 & ,249 \\
\hline Zadovoljstvo raspodjelom poslova &, 320 & $2,619^{* * *}$ &,- 078 &,- 823 \\
\hline Zadovoljstvo raspodjelom financija &,- 002 &,- 020 & ,289 & $3,147^{* * *}$ \\
\hline Zadovoljstvo donošenjem odluka & ,239 & $2,262^{*}$ & ,489 & $4,876^{* * * *}$ \\
\hline$R$ & \multicolumn{2}{|c|}{.48} & \multicolumn{2}{|c|}{.66} \\
\hline$R^{2}$ & \multicolumn{2}{|c|}{.23} & \multicolumn{2}{|c|}{.43} \\
\hline Korigirani $R^{2}$ & \multicolumn{2}{|c|}{.19} & \multicolumn{2}{|c|}{.39} \\
\hline F-omjer & \multicolumn{2}{|c|}{$\mathrm{F}(6 / 102)=5,09^{* * * *}$} & \multicolumn{2}{|c|}{$\mathrm{F}(6 / 90)=11,31^{* * * *}$} \\
\hline Promjena $R^{2}\left(\Delta R^{2}\right)$ & \multicolumn{2}{|c|}{0,20} & \multicolumn{2}{|c|}{0.38} \\
\hline F-omjer & \multicolumn{2}{|c|}{$\mathrm{F}(3 / 102)=8.86^{* * * *}$} & \multicolumn{2}{|c|}{$F(3 / 90)=19,86^{* * * *}$} \\
\hline
\end{tabular}

${ }^{*} p<.05,{ }^{* *} p<.01,{ }^{* * *} p<.001$

U prvom koraku hijerarhijske regresijske analize ni jedna varijabla nije se pokazala značajnim prediktorom doživljaja pravednosti u vezi. U drugom koraku značajni su prediktori za žene zadovoljstvo raspodjelom poslova u kući i zadovoljstvo raspodjelom odlučivanja. Drugim riječima, vezu će doživljavati pravednijom one žene koje su zadovoljnije dijeljenjem kućanskih poslova i odluka s partnerom.

Kod muškaraca doživljaj pravednosti predviđaju zadovoljstvo raspodjelom financijskih izdataka i zadovoljstvo raspodjelom donošenja odluka u vezi. Oba su prediktora pozitivna, što znači da će veći doživljaj pravednosti u vezi imati oni muškarci koji su zadovoljniji načinom raspodjele financija i odlučivanja u vezi.

Odabrani prediktori koji se odnose na raspodjelu ulaganja i zadovoljstvo tom raspodjelom predviđaju 18,5\% ukupne varijance doživljaja pravednosti kod žena, odnosno 39,2\% varijance kod muškaraca.

Dodatno je provjereno doprinose li druge sociodemografske varijable (dob, stupanj obrazovanja, duljina zajedničkog života i broj djece) objašnjenju varijable doživljaja pravednosti. Ni jedna od navedenih varijabli nije se izdvojila kao značajan prediktor, ni u uzorku žena niti muškaraca. 


\section{Rasprava}

\subsection{Percipirana raspodjela partnerskih/obiteljskih obveza i ulaganja}

Brojna istraživanja potvrđuju da žene žele veću ravnopravnost po pitanju rodno određenih uloga, no u stvarnom životu takva ravnopravnost još se uvijek teško pretače u ponašanje (Frieze i sur., 2003.; Bryant, 2003.; Twenge, 1997.; Coltrane, 2000.; Jugović, 2004.; Brajdić-Vuković i sur. 2007.; Kamenov i Jugović, 2011.; Bartolac i sur., 2011.). Kako bismo detaljnije provjerile što znači (ne)ravnopravnost među partnerima na instrumentalnoj razini, tražile smo pojašnjenje na koji način partneri dijele kućanske poslove i brinu se o djeci te kako organiziraju kućni proračun i na koji način donose odluke, gledano kroz njihov subjektivan doživljaj međusobnog ulaganja. Partneri su iskazivali visoku suglasnost u procjeni vlastitog i partnerovog angažmana u poslovima održavanja kućanstva i brige za obitelj. Iz tablice percipirane raspodjele obavljanja kućanskih poslova s niskom i visokom mogućnošću kontrole te brige za druge (tablica 1.) vidljivo je da se i žene i muškarci slažu kako žene više doprinose u rutinskim ili tradicionalno „ženskim poslovima“, dok muškarci više obavljaju povremene („muške“) poslove. Njihovo međusobno slaganje u percepciji vlastitog i partnerovog doprinosa i statistički je potvrđeno, stoga smatramo da je i blisko stvarnom ulaganju. U skladu s time zanima nas koje poslove unutar kuće partneri prepoznaju kako one koje pretežito obavljaju žene, a koje muškarci? Žene apsolutno prednjače u pranju i glačanju rublja (njih oko 87\%), kuhanju (preko $75 \%$ ), čišćenju sanitarnih prostorija te pranju prozora, podova i sl. S druge strane, preko 80\% (do gotovo 90\%) muškaraca vrši popravke u kući i brine se za popravak automobila.

Po pitanju raspodjele brige za djecu među partnerima vidljivo je da većina roditelja smatra kako ulažu jednaku energiju baveći se djetetom (njih 66-69\%), dok oko 20\% smatra da je briga za dijete primarno posao majke. Ovdje je jasno da je varijabla „briga o djetetu“ nedovoljno jasno operacionalizirana i nije sasvim određeno na što se točno odnosi s obzirom da može uključivati svakodnevne rutinske zadatke (koji slijede dnevni ritam potreba djeteta s malo vremenske fleksibilnosti, npr. hranjenje, presvlačenje, kupanje djeteta) u čemu su znatno više angažirane majke (Thomas i Hildingsson, 2009.), ali i bavljenje djetetom prema vlastitom nahođenju (npr. odlazak u šetnju, igra s djetetom) u čemu češće sudjeluju i očevi. Dodatno, briga o djetetu može uključivati i kognitivni aspekt brige koji se odnosi na planiranje, organiziranje i upravljanje svakodnevnim aktivnostima vezanim uz dijete kao i emocionalni aspekt brige (zabrinutost ukoliko je dijete bolesno, briga vezana uz snalaženje u socijalnoj okolini, vrtiću ili školi vezano uz uspjeh i budućnost djeteta i slično). Ove bi varijable svakako valjalo uključiti u buduća istraživanja.

Čini se da je briga za kućnog ljubimca (ukoliko pripada obitelji) najmanje pod utjecajem rodnih razlika. Moguće objašnjenje za ovaj nalaz bila bi kategorizacija aktivnosti brige o kućnom ljubimcu ne u područje kućanskih obveza već u područje slobodnog vremena, pa je članovi obitelji doživljavaju kao razonodu i brigu za vlastito zdravlje (npr. Somervill i sur., 2008.), koja nije rodno određena. 
Većina poslova koji se trebaju napraviti u kući zahtijeva raspodjelu kućnog proračuna. Kuhanje ručka uvjetovano je nabavkom namirnica, briga za djecu kupovinom odjeće i obuće te plaćanjem izdataka za dječje (izvan)školske aktivnosti, a održavanje stambenog prostora opterećeno je troškovima stanarine (kredita), plaćanjem računa i popravaka te kupovinom sredstava za čišćenje. Kako parovi rukovode financijskim sredstvima koja su im na raspolaganju i postoji li na tom polju ravnopravnost ili preferencije? S obzirom da su u svih parova koji su sudjelovali u istraživanju oba partnera zaposlena, jasno je da je financijski doprinos obitelji obostran. Rezultati ukazuju na to da postoji načelna ravnopravnost u dijeljenju svih financijskih obveza u obitelji u skladu s mogućnosti plaćanja (kako je navedeno u upitniku). Ipak se žene više brinu za kupovinu namirnica (u skladu sa $75 \%$ žena koje kuhaju za obitelj) te kupovinu odjeće i obuće (u skladu s većim angažmanom u brizi za djecu). Muškarci se više brinu za plaćanje osiguranja, računa, kućanskih popravaka i troškova za automobil, što je također u skladu s preferiranim i/ili delegiranim poslovima brige za kuću/okućnicu te vlastito/obiteljsko vozilo. Na taj se način ponovno naglašava kako je upravljanje obiteljskim financijama pod snažnim utjecajem tradicionalnih rodnih uloga.

No nije samo kontrola obiteljskih financija povezana s ravnopravnošću među partnerima. Kingsbury (1983.) navodi da je donošenje odluka u vezi jedan od najvažnijih indikatora moći u braku. Čak i kada parovi doživljavaju svoju vezu kao ravnopravnu i svoje rodne uloge kao jednakovrijedne, istraživanja pokazuju da će muževi vjerojatnije imati veći utjecaj na donošenje odluka, što se izjednačava $s$ rodnom neravnopravnošću, te se stoga ova varijabla nikako ne bi smjela izostaviti $\mathrm{u}$ istraživanju rodne ravnopravnosti. U ovom istraživanju najveći broj partnera izjavljuje da odluke donose zajednički. Ipak, u skladu s gore navedenom raspodjelom poslova i financiranja, ponovno žene češće od muškaraca odlučuju koliko će novaca zajedno trošiti na hranu te su odgovorne po pitanju odluka vezanih uz djecu (ni jedna žena ne smatra da njen partner sam donosi odluke vezane uz djecu, što nije slučaj kod muškaraca). S druge strane, očekivano, muškarci češće odlučuju koji će automobil obitelj kupiti. Takva distribucija odlučivanja poznata je i u drugim istraživanjima, primjerice Steil i Weltman (1991.) navode kako je donošenje odluka u suvremenim brakovima podijeljeno u skladu s tradicionalnim rodnim ulogama: žene donose odluke koje se tiču svakodnevnih detalja vezanih uz obiteljski život, a muževi donose velike odluke kao što su odabir mogućnosti vezanih uz karijeru ili raspodjela većih prihoda.

Dakle žene zaista navode kako preuzimaju više rutinskih poslova na sebe, donose odluke u smislu financijskih izdvajanja i realizacije kućanskih poslova, a muškarci to primjećuju i priznaju. No koliko su parovi zapravo zadovoljni takvom raspodjelom investicija? Suitor (1991.:227) ističe da je „u istraživanja kvalitete braka važnije uključiti varijablu zadovoljstva pojedinim aspektom obiteljskog života nego većinu tipičnih demografskih varijabli“ (dob, stupanj obrazovanja ili poslovni status). Zadovoljstvo raspodjelom kućanskih poslova osobito je važno uključiti u istraživanja kvalitete braka za vrijeme promjena uloga, kao što je realizacija roditeljstva, zapošljavanje, povratak u školu ili preuzimanje brige o starijem članu obitelji. To potvrđuje i Jugović (2004.) koja zaključuje da su profesionalna i roditeljska uloga najvažniji prediktori zadovoljstva rodnim ulogama. 
Prosječno zadovoljstvo raspodjelom svih ulaganja relativno je visoko kod žena i muškaraca, no razlike ipak postoje u zadovoljstvu preuzetim obavljanjem kućanskih poslova i raspodjelom financija, na što ukazuju dobiveni rezultati (tablica 2.). Žene su najmanje zadovoljne raspodjelom kućanskih poslova, dok su muškarci najviše zadovoljni raspodjelom financija. Ovakav nalaz potvrđuje i Kluwer sa suradnicima (1997.) u svom istraživanju, a sasvim je razumljiv ako se sagleda iz perspektive ženinog većeg opterećenja u području obavljanja kućanskih poslova i brige za djecu te muškarčevog rasterećenja kao jedinog izvora financijskih resursa u obitelji. U skladu su s time i naši rezultati (tablica 3.) prema kojima su žene to zadovoljnije percipiranom raspodjelom kućanskih poslova što se njihov partner više uključuje, dok su i muškarci i žene najzadovoljniji ako oboje doprinose kućnim financijama, a najmanje zadovoljni ako sami snose taj teret. Kamenov i suradnice (2007.) navode da je zadovoljstvo obaju partnera najveće ako podjednako dijele svakodnevne poslove u kući. No u slučaju kada je raspodjela poslova nejednaka, žene koje više doprinose obavljanju kućanskih poslova ujedno su i najmanje zadovoljne, što je u skladu i s rezultatima ovog istraživanja. Također se u spomenutom istraživanju navodi da jednakost u raspodjeli svih partnerskih ulaganja, pa i financija, ipak donosi najveće zadovoljstvo za oba partnera, što je odmak od tradicionalne uloge muškarca kao izvora resursa za obitelj. U našem istraživanju također su oba partnera najzadovoljnija ako zajednički sudjeluju u financiranju i donošenju obiteljskih odluka. Upravo po pitanju zadovoljstva donošenjem odluka u vezi nije dobivena značajna razlika među spolovima. S obzirom da je na toj skali iskazana najveća ravnopravnost, takav je nalaz očekivan.

Gray i Evans (2008.) istražile su postoji li razlika između bračnih i vanbračnih zajednica u smislu dijeljenja osobnog dohotka. Njihovo je istraživanje potvrdilo da parovi koji su u formalnom braku češće spajaju svoje prihode u zajedničku „obiteljsku blagajnu“ iz koje se izdvaja novac za obiteljske troškove. One smatraju da je zajednička blagajna izraz povjerenja među partnerima. Parovi koji su u kohabitaciji rjeđe spajaju vlastiti prihod s partnerovim u zajednički proračun, no to ne mora biti pravilo (osobito u situacijama većih zajedničkih investicija). U naših se parova nije pokazala povezanost oblika partnerske zajednice sa zadovoljstvom dijeljenjem financijskih izdataka.

\subsection{Doživljaj pravednosti u vezi}

Korištena skala pravednosti obuhvaća pitanja ravnopravnosti u dijeljenju svakodnevnih poslova i obveza kao i općeniti doživljaj pravednosti u smislu ravnoteže dobitaka i gubitaka u vezi u skladu s teorijom socijalne razmjene. Ćubela Adorić i Mičić (2010.:53) pojašnjavaju da pravednost u kontekstu partnerskih odnosa počiva na „distributivnoj pravednosti [...] odnosno proporcionalnosti ili jednakosti omjera doprinosa i dobitaka iz veze kod jednog i drugog partnera“. Stoga su analizirane razlike u doživljaju pravednosti među partnerima (žene i muškarca u pojedinom paru kao zavisni podaci) i prema ukupnom rezultatu i na razini pojedinih čestica skale. Prema prvom kriteriju pokazalo se da žene doživljavaju odnos u vezi manje pravednim $(\mathrm{t}=7,213, \mathrm{df}=110, \mathrm{p}<.001)$, što je u skladu s nalazima autorica skale (Ćubela Adorić i Mičić, 2010.). Iako se parovi slažu u općenitim izjavama da nitko 
ne profitira na račun onoga drugoga kao i da kada se sve zbroji i oduzme, nitko od njih zapravo nije na gubitku, u ostalim česticama pronađene su značajne razlike između partnerice i partnera. Opći dojam pravednosti ukazuje na to da se žene više osjećaju „zakinute“, odnosno kao one koje se više „odriču i žrtvuju“, dok je partner u njihovoj vezi „prošao bolje“.

Što zapravo predviđa doživljaj pravednosti u vezi? Coltrane (2000.) je analizirao istraživanja koja su se tom temom bavila devedesetih godina prošlog stoljeća i na osnovu proučavanja dobivenih rezultata zaključio da na doživljaj pravednosti utječu tri osnovna prediktora: radno vrijeme, obrazovanje i stavovi. Primjerice, ukoliko muškarac radi prekovremeno ili ima više obrazovanje od žene, njegova će partnerica nejednaku raspodjelu kućanskih poslova doživljavati kao pravedniju. Nepravednost u nejednakoj raspodjeli poslova vidjet će oba partnera koja su visoko obrazovana ili imaju egalitarnije stavove prema rodnim ulogama. U obradu rezultata našeg istraživanja uključili smo varijable dobi, stupnja obrazovanja, duljinu zajedničkog života i broj djece, no ni jedna se nije pokazala kao značajan prediktor za kriterij doživljaja pravednosti.

Kako bi se dobio odgovor na pitanje doprinosi li doživljaju pravednosti percepcija raspodjele obiteljskih obveza ili zadovoljstvo tom raspodjelom, provedena je hijerarhijska regresijska analiza, pri čemu se prva skupina prediktora odnosila na percipiranu raspodjelu partnerskih ulaganja, dok je druga skupina prediktora obuhvaćala zadovoljstvo tom raspodjelom. Percipirana raspodjela poslova u prvom koraku hijerarhijske regresijske analize (tablica 4.) nije se pokazala značajnim prediktorom ni za ženski ni za muški dio uzorka. U drugom koraku dodane su nove prediktorske varijable zadovoljstva percipiranom raspodjelom poslova/financija/odlučivanja, koje su ukazale na sljedeće: značajni su prediktori doživljaja pravednosti u vezi za žene zadovoljstvo percipiranom raspodjelom poslova u kući te zadovoljstvo donošenjem odluka. To znači da vezu pravednijom doživljavaju one žene u čijem kućanstvu percipirana raspodjela poslova i odlučivanja ne odstupa od njihovih očekivanja. Objašnjenje doživljaja pravednosti kod žena zadovoljstvom raspodjele kućanskih poslova očekivana je s obzirom da su muškarci, za razliku od žena, gotovo univerzalno zadovoljni raspodjelom kućanskih poslova. Žene su manje zadovoljne ako su one te koje obavljaju većinu poslova bez sudjelovanja partnera te ako su ujedno egalitarnih stavova prema rodnim ulogama i vole svoju profesiju (Baxter i Western, 1998., prema Coltrane, 2000.).

Kod muškaraca doživljaj pravednosti predviđaju sljedeće varijable: zadovoljstvo percipiranom raspodjelom financijskih izdataka i zadovoljstvo percipiranom raspodjelom donošenja odluka u vezi. Prema tome veći doživljaj pravednosti u vezi imat će oni muškarci koji su i zadovoljniji načinom raspodjele financija i odlučivanja u vezi. Usprkos tome što je sposobnost pribavljanja resursa jedan od identificirajućih čimbenika tradicionalne muške rodne uloge te izvor moći i statusa, naši nalazi pokazuju da su muškarci, kao i žene, najzadovoljniji ako oba partnera sudjeluju u financiranju obiteljskih troškova, a najmanje su zadovoljni ako su jedini financijski odgovorni za obitelj. Kako se radi o uzorku dvohraniteljskih obitelji, čini se da su muškarci prilagodili i svoja očekivanja o rodnim ulogama te prepustili suprugama i dio financijske odgovornosti za obitelj. 
Zadovoljstvo percipiranom raspodjelom u donošenju odluka najjači je prediktor doživljaja pravednosti za muškarce, no predviđa i doživljaj pravednosti kod žena. Kako su naši rezultati pokazali da su i jedni i drugi najzadovoljniji kada oboje ravnopravno donose obiteljske odluke, dobiveni nalaz ukazuje na to da zajedničko donošenje odluka pridonosi doživljaju veze pravednijom. S obzirom da se radi o dvohraniteljskim obiteljima, navedeni je nalaz razumljiv. Obostrani doprinos obiteljskom proračunu izjednačava odnos moći među partnerima, što uključuje i zajedničko donošenje odluka vezanih uz obitelj.

Zanimljivo je da su slične rezultate hijerarhijske regresijske analize dobile Kamenov i suradnice (2007.) s kriterijskom varijablom ukupnog zadovoljstva vezom. Ova bi potvrda stoga mogla upućivati na blisku povezanost varijable doživljaja pravednosti i ukupnog zadovoljstva vezom. Značajnu povezanost rezultata na Skali percipirane pravednosti u braku i Skali bračnog zadovoljstva uočile su i Ćubela-Adorić i Mičić (2010.), te sugeriraju da se doživljaj pravednosti ispitan ovom skalom može koristiti i kao pokazatelj ukupne kvalitete bračnog odnosa.

Važno je napomenuti da odabrani prediktori koji se odnose na percipiranu raspodjelu ulaganja i zadovoljstvo tom raspodjelom snažnije predviđaju doživljaj pravednosti kod muškaraca (s objašnjenih 39,2\% varijance) nego kod žena (tek 18,5\% ukupne varijance), kao i da zadovoljstvo i pravednost nisu isti konstrukti. Čini se da bi doživljaj pravednosti, osobito kod žena, mogle predviđati neke, u ovom istraživanju sasvim nedotaknute, varijable koje bi trebalo dodatno istražiti. Valja uzeti u obzir da odnos partnera u vezi, njihov način komunikacije, aktivno slušanje, uvažavanje i zajedničko rješavanje problema zasigurno utječu na osjećaj pravednosti. Naime Wilkie, Ferree i Ratcliff (1998.) potvrdili su da će partneri koji imaju poteškoće sa započinjanjem razgovora o problemima i ne uspijevaju uključiti partnera u proces rješavanja problema vjerojatnije doživljavati podjelu uloga u vezi nepravednom.

Općenito gledajući, nedostatak ovog istraživanja odnosi se na premali broj sudionika/parova na osnovi kojih bismo mogli donositi uopćene zaključke, kao i na to da su sudionici zasigurno selekcionirani voljnošću sudjelovanja u istraživanju te većinskim udjelom osoba koje žive u gradskoj sredini i višim stupnjem obrazovanja, što sveukupno ne može reprezentirati populaciju. No s obzirom da su rezultati vrlo sukladni najnovijim istraživanjima koja se bave ovom temom, osobito u Hrvatskoj, može se govoriti o aktualnosti zaključaka. Iako je veličina i prigodnost uzorka sudionika određeni nedostatak istraživanja, velika mu je prednost to što je provedeno na parovima. Naime istraživanja ove teme u nas iznimno su rijetka, a kada se i provode rijetko se usmjeravaju na parove kao zavisan uzorak. Najčešće se istraživanja ove teme provode na uzorcima muškaraca i žena koji ne moraju biti međusobno povezani a razlog je vrlo praktičan: vrlo je teško prikupiti podatke od obaju partnera i osipanje je podataka jako veliko (u našem istraživanju vratilo se tek oko 40\% podijeljenih upitnika). Dodatno, ovo je uzorak parova u kojima su oba partnera zaposlena, tako da možemo govoriti o dvohraniteljskim obiteljima bez djece ili $\mathrm{s}$ djecom različitog uzrasta. 
Preporuke za daljnja istraživanja odnosile bi se na dobivanje uvida u opterećenost partnera drugim aktivnostima vezanim uz obitelj, kao što su: poslovi organiziranja i upravljanja u obitelji, pomaganje partneru u njegovom poslu i rad na poboljšanju statusa bračnog partnera, jasnije operacionalizirani brojni roditeljski zadaci (varijabla „briga za djecu“ detaljnije razrađena i opisana), njega i briga za bolesne, stare ili nemoćne članove obitelji zajedno s emocionalnim angažmanom u obitelji (ČudinaObradović i Obradović, 2006.; Meier i sur., 2006.).

Posebno bi bilo zanimljivo ispitati utječu li međusobna ljubav i poštovanje prema partnerici na veće sudjelovanje partnera u poslovima u kući i brizi za djecu, budući da se to pokazalo kao područje najvećih rodnih razlika, kao i na doživljaj pravednosti u vezi. Na kraju, doživljaj pravednosti u vezi trebalo bi dodatno istražiti nekim novim prediktorima, budući da oni koji su korišteni u ovom istraživanju objašnjavaju manji postotak varijance, osobito za ženski dio uzorka.

\section{Zaključak}

Cilj ovog istraživanja bio je utvrditi postoji li razlika među partnerima po pitanju raspodjele partnerskih ulaganja vezanih uz obavljanje svakodnevnih poslova u domaćinstvu, brigu za djecu, raspodjelu kućnog proračuna te donošenje obiteljskih odluka. Pritom su korištene mjere percepcije vlastitog i partnerovog ulaganja u navedene obiteljske poslove. Ujedno smo htjeli utvrditi koliko su partneri zadovoljni dijeljenjem obiteljskih obveza te koliko su navedene varijable povezane s doživljajem pravednosti kod obaju partnera.

Rezultati su pokazali da se u području raspodjele poslova u organizaciji domaćinstva partneri slažu da su žene te koje više doprinose u rutinskim ili tradicionalno doŽivljenim „ženskim poslovima“, dok muškarci više obavljaju povremene („muške“) poslove. Međutim raspodjela financija i sudjelovanje u odlučivanju uglavnom je zajedničko i ravnopravno.

Koliko su partneri zadovoljni doprinosom pri raspodjeli obiteljskih investicija? Zadovoljstvo raspodjelom obavljanja kućanskih poslova kao i raspodjelom financija kod žena manje je nego u muškaraca. Jedino su po pitanju donošenja odluka u vezi muškarci i žene jednako zadovoljni. Oba partnera najzadovoljnija su kada podjednako sudjeluju u obiteljskim troškovima i donošenju odluka, dok su što se tiče podjele kućanskih poslova muškarci uvijek zadovoljni, a žene to zadovoljnije što se partner više uključuje.

Je li raspodjela ulaganja i zadovoljstvo tom raspodjelom povezana s doživljajem pravednosti u vezi? Rezultati pokazuju da žene doživljavaju odnos u vezi manje pravednim nego muškarci. Doživljaj pravednosti u vezi najbolje se može predvidjeti zadovoljstvom donošenjem odluka i raspodjelom financija kod muškaraca, te zadovoljstvom raspodjelom kućanskih poslova i donošenjem odluka u žena. Prema tome za doživljaj pravednosti u vezi važnije je koliko su partneri zadovoljni pojedinač- 
nim ulaganjem u obitelj (ili koliko je ta raspodjela u skladu s njihovim očekivanjima) od njihove percepcije raspodjele ulaganja.

Zaključno, prema rezultatima ovog istraživanja čini se da u pogledu raspodjele kućanskih poslova i dalje opstaju odnosi koji su pod utjecajem tradicionalnih rodnih uloga. Žene se i dalje u obitelji primarno bave domaćinstvom unatoč tome što su zaposlene i izvan doma. Stoga ne začuđuje doživljaj nepravednosti u žena s obzirom na njihovo nezadovoljstvo svakodnevnim (dvostrukim) opterećenjem poslovima na radnom mjestu i u obitelji. Ravnopravnost u raspodjeli obiteljskih obveza omogućila bi im ostvarenje drugih socijalnih uloga u kojima žele sudjelovati i napredovati, te vjerojatno povećala zadovoljstvo i doživljaj pravednosti u vezi.

Ipak, čini se da je u dvohraniteljskim obiteljima postignuta veća ravnopravnost u pogledu raspodjele financijske odgovornosti i sudjelovanja u donošenju odluka. Iako tradicionalne rodne uloge podrazumijevaju da ova područja pripadaju muškoj domeni, dobiveni rezultati pokazuju da je uključivanje žena u ulogu drugog hranitelja obitelji dovelo i do ravnopravnije podjele moći među partnerima.

\section{Literatura}

1. Bartley, S. J.; Blanton, P. W. and Gilliard, J. L. (2005). Husbands and Wives in Dual-Earner Marriages:Decision-Making, Gender Role Attitudes, Division of Household Labor and Equity. Marriage E Family Review, 37 (4): 69-94.

2. Bartolac, A.; Kamenov, Ž. i Petrak, O. (2011). Rodne razlike u obiteljskim ulogama, zadovoljstvu i doživljaju pravednosti s obzirom na tradicionalnost stava. Revija za socijalnu politiku, 18 (2): 175-194.

3. Baxter, J.; Hewitt, B. and Haynes, M. (2004). Transitions through the Lifecourse and Time Spent on Housework. Conference Papers: American Sociological Association, 1-24.

4. Bittman, M.; England, P.; Sayer, L.; Folbre, N.; Matheson, G. (2003). When does gender trump money? Bargaining and time in household work. American Journal of Sociology, 109: 186-214.

5. Brajdić-Vuković, M.; Birkelund, G. E. and Štulhofer, A. (2007). Between Tradition and Modernization Attitudes Toward Women's Employment and Gender Roles in Croatia. International Journal of Sociology. 37 (3): 32-53.

6. Brines, J. (1994). Economic dependency, gender, and the division of labor at home. American Journal of Sociology, 100: 652-688.

7. Bryant, A. (2003). Changes in Attitudes Toward Women's Roles: Predicting Gender-Role Traditionalism Among College Students. Sex Roles, 48 (3/4): 131-142.

8. Coltrane, S. (2000). Research on Household Labour: Modelling and Measuring the Social Embeddedness of Routine Family Work. Journal of Marriage E Family, 62 (4): 1208-1233.

9. Coltrane, S. and Shih, K. Y. (2010). Gender and the division of labor, in: J. C. Chrisler and D. R. McCreary (Eds.). Handbook of Gender Research in Psychology. New York: Springer.

10. Čudina-Obradović, M. i Obradović, J. (2006). Psihologija braka i obitelji. Zagreb: Golden Marketing - Tehnička knjiga. 
11. Ćubela Adorić, V. i Mičić, L. (2010). Skala percipirane pravednosti u braku, u: Tucak Junaković, I.; Ćubela Adorić, V.; Penezić, Z.; Proroković, A. (Ur.). Zbirka psibologijskih skala i upitnika V. Zadar: Sveučilište u Zadru.

12. Ćubela Adorić, V. i Jurević, J. (2006). Prikaz Upitnika percepcije kvalitete bračnog odnosa. Rukopis. Zadar.

13. Državni Zavod za statistiku Republike Hrvatske (2009). Žene $i$ muškarci u Hrvatskoj 2009. Zagreb: Državni Zavod za statistiku Republike Hrvatske.

14. Frieze, I. H.; Ferligoj, A.; Kogovšek, T.; Rener, T.; Horvat, J.; Šarlija, N. (2003). Gender-role Attitudes in University Students in the United States, Slovenia and Croatia. Psychology of Women Quarterly, 27: 256-261.

15. Goñi-Legaz, S.; Ollo-López, A. and Bayo-Moriones, A. (2010). The Division of Household Labor in Spanish Dual Earner Couples: Testing Three Theories. Sex Roles, 63 (7/8): 515-529.

16. Gray, E. and Evans, A. (2008). Do Couples Share Income? Variation in the Organisation of Income in Dual-Earner Households. Australian Journal of Social Issues, 43 (3): 441-457.

17. Greenstein, T. (2000). Economic Dependence, Gender, and the Division of Labor in the Home: A Replication and Extension. Journal of Marriage \& Family, 62: 322-335.

18. Gunter, N. C. and Gunter, B. G. (1990). Domestic Division of Labor Among Working Couples. Psychology of Women Quarterly, 14 (3): 355-370.

19. Homans, G. (1961). Social Behavior. New York: Harcourt, Brace \& World.

20. Johnson, J. A. (2010). Using Gender: The Personal, Interpersonal, and Emotional Strategies of Domestic Labor. Sociological Spectrum, 30 (6): 695-724.

21. Jugović, I. (2004). Zadovoljstvo rodnim ulogama. Diplomski rad. Filozofski fakultet Sveučilišta u Zagrebu.

22. Jugović, I. i Kamenov, Ž. (2011). Rodna (ne)ravnopravnost i diskriminacija u obiteljskim odnosima, u: Kamenov, Ž. i Galić, B. (Ur.). Rodna ravnopravnost $i$ diskriminacija u Hrvatskoj: Istraživanje «Percepcija, iskustva i stavovi o rodnoj diskriminaciji $u$ RH». Zagreb: Ured za ravnopravnost spolova Vlade RH.

23. Kamenov, Ž.; Jelić, M.; Tadinac, M.; Hromatko, I. (2007). Quality and stability of the relationship as a function of distribution of housework, financial investments and decision making between partners. Psychology Days in Zadar: Book of Selected Proceedings.

24. Kamenov, Ž. i Jugović, I. (2011). Percepcija, iskustvo i stavovi o rodnoj (ne) ravnopravnosti u obitelji, u: Kamenov, Ž. i Galić, B. (Ur.). Rodna ravnopravnost i diskriminacija u Hrvatskoj: Istraživanje «Percepcija, iskustva i stavovi o rodnoj diskriminaciji $u$ RH». Zagreb: Ured za ravnopravnost spolova Vlade RH.

25. Kelley, H. H. and Thibaut, J. (1978). Interpersonal relations: A theory of interdependence. New York: Wiley

26. Kingsbury, N. (1983). An Assessment of Decision-Making Processes in Dual-Career Marriages. Annual Meeting of the National Council on Family Relations. 11-15.

27. Kluwer, E. S.; Heesink, J. M. and Van De Vliert, E. (1997). The Marital Dynamics of Conflict over the Division of Labor. Journal of Marriage E Family, 59 (3): 635-653. 
28. Leinert Novosel, S. (1999). Žena na pragu 21. stoljeća - između majčinstva $i$ profesije. Zagreb: Ženska grupa TOD i EDAC.

29. Lennon, M. and Rosenfield, S. (1994). Relative Fairness and the Division of Housework: The Importance of Options. American Journal of Sociology, 100 (2): 506-531.

30. Lindsay, J. (1999). Diversity But Not Equality: Domestic Labour in Cohabiting Relationships. Australian Journal of Social Issues, 34 (3): 267-283.

31. Major, B. (1993). Gender, Entitlement, and the Distribution of Family Labor. Journal of Social Issues, 49 (3): 141-159.

32. Man Yee, K. (2008). Measuring Housework Participation: The Gap between "Stylised" Questionnaire Estimates and Diary-based Estimates. Social Indicators Research, 86 (3): 381-400.

33. Mederer, H. (1993). Division of Labor in Two-Earner Homes: Task Accomplishment Versus Household Management as Critical Variables in Perceptions About Family Work. Journal of Marriage E Family, 55 (1): 133-145.

34. Meier, J.; McNaughton-Cassill and M., Lynch, M. (2006). The Management of Household and Childcare Tasks and Relationship Satisfaction in Dual-Earner Families. Marriage \& Family Review, 40 (2/3): 61-88.

35. Potuchek, J. (1992). Employed Wives' Orientations to Breadwinning: A Gender Theory. Journal of Marriage E Family, 54 (3): 548-558.

36. Pyke, K. (1994). Women's employment as a gift or burden? Marital power across marriage, divorce, and remarriage. Gender \& Society, 8: 73-91.

37. Rogers, S. J. and Amato, P. R. (2000). Have Changes in Gender Relations Affected Marital Quality?. Social Forces, 79 (2): 731-753.

38. Ruppanner, L. (2008). Fairness and Housework: A Cross-National Comparison. Journal of Comparative Family Studies, 39 (4): 509-526.

39. Somervill, J.; Kruglikova, Y.; Robertson, R.; Hanson, L.; MacLin, O. (2008). Physiological Responses by College Students to a Dog and a Cat: Implications for Pet Therapy. North American Journal of Psychology, 10 (3): 519-528.

40. Steil, J. M. and Weltman, K. (1991). Marital Inequality: The Importance of Resources, Personal Attributes, and Social Norms on Career Valuing and the Allocation of Domestic Responsibilities. Sex Roles, 24 (3/4): 161-179.

41. Suitor, J. (1991). Marital Quality and Satisfaction with the Division of Household Labor across the Family Life Cycle. Journal of Marriage \& Family, 53 (1): 221230.

42. Sullivan, O. (1997). The division of housework among «remarried» couples. Journal of Family Issues, 18: 205-223.

43. Tadinac, M.; Kamenov, Ž.; Jelić, M.; Hromatko, I. (Ur.). (2007). Što ljubavnu vezu čini uspješnom? Izvještaj s XV. Ljetne psihologijske škole. Zagreb: Odsjek za psihologiju Filozofskog fakulteta u Zagrebu

44. Thomas, J. E. and Hildingsson, I. (2009). Who's bathing the baby? The division of domestic labour in Sweden. Journal Of Family Studies, 15 (2): 139-152.

45. Tichenor, V. (2005). Maintaining men's dominance: Negotiating identity and power when she earns more. Sex Roles, 53: 191-205.

46. Tomić-Koludrović i I., Kunac, S. (2000). Rizici modernizacije: žene u Hrvatskoj devedesetih. Split: Udruga građana "Stope nade". 
47. Topolčić, D. (2001). Muškarci to ne rade: Rodno segregirana podjela rada u obitelji. Društvena istraživanja, 10 (4/5): 767-789.

48. Twenge, J. M. (1997).Attitudes Toward Women, 1970-1995: A Meta-Analysis. Psychology of Women Quarterly, 21: 35-52.

49. Walster, E.; Walster, G.W. and Berscheid, E. (1978). Equity: Theory and research. Boston: Allyn and Bacon

50. Wilkie, J.; Ferree, M. and Ratcliff, K. (1998). Gender and Fairness: Marital Satisfaction in Two-Earner Couples. Journal of Marriage E Family, 60 (3): 577-594. 
Izvorni znanstveni rad

\title{
Andreja Bartolac
}

University of Applied Health Studies, Zagreb, Croatia

e-mail: andreja.bartolac@zvu.hr

\section{Željka Kamenov}

Faculty of Humanities and Social Sciences, Department of Psychology, University of Zagreb, Croatia

e-mail: zkamenov@ffzg.hr

\section{Perceived Distribution of Family Obligations Between Partners and Perception of Equity in a Relationship}

\begin{abstract}
Research results over the past twenty years have shown that both men and women agree that family duties should be shared more equitably between partners. However, this responsibility is not exercised accordingly in everyday life. The aim of this study was to find out how partners perceived the distribution of daily duties and responsibilities in their relationship (household chores, management of finances and decision making) and how satisfied they were with such a distribution. Also we wanted to find out whether men and women perceived equity in a relationship differently and which was a better equity predictor: the distribution of family responsibilities or the satisfaction with it? The study included 120 dual-income couples. The results show that women still contribute more to routine or traditionally female chores, while men do periodical or traditionally male household chores. Women are less satisfied than men with this division of housework and finance. Both partners are most satisfied when they participate equally in family expenses and decisions. Men's experience of equity in a relationship is best predicted by their satisfaction with shared finances and women's by their satisfaction with shared household tasks. For both partners, satisfaction with shared decisionmaking is a significant predictor.
\end{abstract}

Key words: distribution of partners' responsibilities, satisfaction, equity, two-income couples. 